\title{
Involvement of Distinct Signaling Pathways in Activin- Induced Increases in FSH Secretion and Enlargement of FSH Cell Population in the Rat Pituitary
}

\author{
Tetsuro KATAYAMA, Hisako KYAN, Michiko NAKASHiMA, Emilliana Y. RAHAYU, \\ NOBORU MURAKAMI AND HARUTO KURODA
}

Department of Veterinary Physiology, Faculty of Agriculture, Miyazaki University, 1-1 Gakuenkibanadai-Nishi, Miyazaki 889-2192, Japan

\begin{abstract}
Activin-A induces increases in FSH secretion, as well as the number of immunoreactive FSH cells, in cultured rat pituitary cells. In this study, we examined whether mechanisms involved in these two actions of activin-A are identical or not, with respect to the involvement of cellular proliferation and of $\mathrm{Ca}^{2+}$-dependent signaling pathways. Treatment with activin-A $(25 \mathrm{ng} / \mathrm{ml})$ for $48 \mathrm{~h}$ caused increases in the number of cultured rat anterior pituitary cells that incorporated BrdU, a thymidine analog. The stimulatory effects of activin-A on FSH secretion and on the percentage of immunoreactive FSH cells were, however, not inhibited by the presence of the mitotic inhibitor cytosine arabinoside. On the other hand, the stimulatory effect of activin-A on the percentage of immunoreactive FSH cells was completely blocked in the presence of the $\mathrm{Ca}^{2+} /$ calmodulin kinase inhibitor $\mathrm{KN}-62$ or the L-type $\mathrm{Ca}^{2+}$ channel blocker nicardipine. Neither of these inhibitors, however, revealed significant influence on the effect of activin-A on FSH secretion. These results suggest that activin-A exhibits its dual effect on FSH cells without causing cellular proliferation. Furthermore, activin-A appears to induce increases in FSH secretion and enlargement of FSH cell population through distinct intracellular signaling pathways, the former through $\mathrm{Ca}^{2+}$-independent and the latter through $\mathrm{Ca}^{2+}$-dependent mechanisms.
\end{abstract}

Key words: Activin, Calcium, Pituitary, Proliferation, Rat

(Endocrine Journal 47: 239-247, 2000)

ACTIVINS belong to the transforming growth factor (TGF)- $\beta$ superfamily [1], and were originally isolated from ovarian follicular fluid on the basis of their ability to stimulate secretion and synthesis of FSH from cultured pituitary cells $[2,3]$. Immediately after the discovery of activins, Eto and his colleagues $[4,5]$ proved that one of the activin molecules, activin-A (a dimer of the $\beta \mathrm{A}$-subunits), is identical to erythroid differentiation factor which has a potent differentiation-inducing activity on murine Friend

Received: July 22, 1999

Accepted: March 8, 2000

Correspondence to: Dr. Tetsuro KATAYAMA, Gene Research Center, Miyazaki University, 1-1 GakuenkibanadaiNishi, Miyazaki 889-2192, Japan erythroleukemia cells. Subsequent studies have demonstrated multiple actions of activins, as well as the expression of activin subunits [6], in a variety of tissues.

In addition to stimulating the secretion and synthesis of FSH, activin-A possesses an activity to induce increases in the number of immunoreactive FSH cells in cultured rat anterior pituitary cells [7, 8]. Our study using the centrifugal elutriation method revealed that cells responsible for activin-induced increases in FSH secretion and those for activin-induced increases in the number of FSH cells belonged to distinct fractions [9], suggesting that distinct cell populations are responsive to activin-A in the dual action. Based on these observations, the present study examined whether the mechanisms involved in 
the two actions of activin-A are identical or not, in terms of involvement of cellular proliferation and of the intracellular signaling pathway.

\section{Materials and Methods}

\section{Reagents}

Human recombinant activin-A was kindly provided by Dr. Y. Eto, Central Research Laboratory of Ajinomoto Co., Kawasaki, Japan. Dulbecco's modified Eagle medium, HEPES buffer solution, trypsin-EDTA, bovine serum albumin (fraction V; BSA) and fetal bovine serum (FBS) were purchased from GIBCO (Grand Island, NY, USA); defined medium supplements (insulin-transferrin-sodium selenite), putrescine, fibronectin, penicillin-streptomycin solution, poly-L-lysine, A23187 (calcium ionophore), $\mathrm{KN}-62\left(\mathrm{Ca}^{2+} /\right.$ calmodulin kinase inhibitor), nicardipine (L-type $\mathrm{Ca}^{2+}$ channel blocker), 5bromo-2'-deoxyuridine (BrdU) and cytosine arabinoside were from Sigma (St. Louis, MO, USA); BrdU monoclonal antibody was from DAKO Japan (Kyoto, Japan); rat FSH antibody (rabbit) for immunocytochemistry and anti-rabbit precipitating antibody were from Biogenesis (Poole, England); and other general reagents were from Nacalai tesque (Kyoto, Japan).

\section{Primary culture of rat anterior pituitary cells}

Anterior pituitaries from 10 to 15 week-old male Sprague-Dawley rats were enzymatically dispersed by the collagenase-based method reported previously [8]. Dispersed cells were suspended in Dulbecco's modified Eagle medium supplemented with $20 \mathrm{mM}$ HEPES, $50 \mathrm{U} / \mathrm{ml}$ penicillin, $50 \mu \mathrm{g} / \mathrm{ml}$ streptomycin (DMEM) and 10\% (v/v) decomplemented FBS. The cells were placed in culture dishes (48- or 6-well multiwell plates; Falcon, Bedford, MA, USA) at a density of $1 \times 10^{5}$ cells $/ \mathrm{cm}^{2}$ and were precultured for 2 days under a saturated atmosphere of $5 \% \mathrm{CO}_{2}-95 \%$ air at $37^{\circ} \mathrm{C}$. After intensive washes with DMEM, the cells were further cultured for 48 or $72 \mathrm{~h}$ in serumfree medium, DMEM supplemented with $5 \mu \mathrm{g} / \mathrm{ml}$ insulin, $5 \mu \mathrm{g} / \mathrm{ml}$ transferrin, $5 \mu \mathrm{g} / \mathrm{ml}$ sodium selenite, $200 \mu \mathrm{M}$ putrescine and $1 \mu \mathrm{g} / \mathrm{ml}$ fibronectin. Experimental materials, such as activin-A, BrdU, cyto- sine arabinoside, $\mathrm{KN}-62$ or nicardipine, were added during these peroids.

In experiments to test the effects of activin-A, media were removed from 48-well plates and assayed for FSH by radioimmunoassay. Cells were solubilized in phosphate-buffered saline containing $0.1 \%(\mathrm{v} / \mathrm{v})$ Triton X-100 and $0.1 \%(\mathrm{w} / \mathrm{v})$ BSA and assayed for cellular content of FSH by RIA. For immunocytochemistry, cells were detached from 6-well plates with $0.05 \%(\mathrm{w} / \mathrm{v})$ trypsin- $0.02 \%(\mathrm{w} / \mathrm{v})$ EDTA, resuspended in DMEM and applied to poly-L-lysinecoated 4-well Lab-Tek chamber slides (Nunc, Rochester, NY, USA) to allow attachment. To test effectiveness of KN-62, cells were washed and further incubated in DMEM-0.1\% BSA containing A23187 for $4 \mathrm{~h}$. For the evaluation of the effectiveness of nicardipine, cells were washed and incubated for $4 \mathrm{~h}$ in high potassium basal salt solution $(75.4 \mathrm{mM} \mathrm{NaCl}$, $60 \mathrm{mM} \mathrm{KCl}, 1.8 \mathrm{mM} \mathrm{CaCl}_{2}, 5.5 \mathrm{mM}$ glucose, $1.3 \mathrm{mM}$ $\mathrm{MgSO}_{4}, 20 \mathrm{mM}$ HEPES, $0.1 \%$ BSA). FSH in media and cellular content of FSH were measured as described above. Final concentrations of DMSO to solubilize $\mathrm{KN}-62$, nicardipine and A23187 did not exceed $0.2 \%$, and this concentration of DMSO did not affect experimental results.

\section{Radioimmunoassay}

NIDDK-rFSH-I-8 was iodinated by a modified chloramine-T method [10], and NIDDK-anti-rFSHS-11 was used as the primary antibody. Bound and free hormone were separated with anti-rabbit precipitating antibody (sheep anti-rabbit immunoglobulins immobilized on silica beads). FSH determinations were expressed in terms of NIDDK-rFSH-RP-2.

\section{Immunocytochemistry}

Cells attached to 4-well Lab-Tek chamber slides were fixed with Bouin's solution (without acetic acid) for $10 \mathrm{~min}$ at room temperature $\left(23 \pm 2^{\circ} \mathrm{C}\right)$. For BrdU staining, cells were further treated with $1 \mathrm{M}$ $\mathrm{HCl}$ for $20 \mathrm{~min}$ at room temperature to denature DNA. Cells were immunostained as previously reported [8] using the streptavidin-biotin-peroxidase method (a kit from ZYMED Laboratories, South San Francisco, CA, USA). Incubation with the primary antibody, anti-rat FSH $(1: 1,500)$ or anti-BrdU $(1: 50)$, was performed for $1 \mathrm{~h}$ at room temperature. 
Specificity of anti-rat FSH was examined by pre-incubation of the antibody with excess amount of rat FSH (NIDDK-r-FSH-I-8) or rat LH (NIDDK-r-LHI-9). Percentage of immunostained cells was determined by counting more than 300 pituitary cells for a slide while noting the number of stained cells under a light microscope.

\section{Statistical analysis}

Data are expressed as the mean \pm SEM of quadruplicate samples from representative experiments. Similar results were obtained in at least three independent experiments. Differences were statistically evaluated by one-way or two-way ANOVA, and Student-Newman-Keuls test was used as a post-hoc test. $\mathrm{P}<0.05$ was considered significant.

\section{Results}

\section{Specificity of anti-rat FSH used for immunocyto- chemistry}

The specificity of anti-rat FSH was examined by incubation of the antibody $(1: 1,500)$ with excess amount $(12.5 \mu \mathrm{g} / \mathrm{ml})$ of rat FSH or rat $\mathrm{LH}$ for $24 \mathrm{~h}$ at $4^{\circ} \mathrm{C}$ before being applied to immunocytochemistry. As shown in Table 1, the immunoreaction of the antibody was abolished by pre-incubation with rat FSH, whereas it was not significantly affected by pre-incubation with rat LH. These results indicate that the FSH antibody, at the concentration used in the present study, showed little cross-reaction with LH and, therefore, virtually detected FSH cells specifically.
Dose-dependent effects of activin- $A$ on FSH secretion and the percentage of immunoreactive FSH cells

Cells were cultured in the presence or absence of activin-A $(10,20,40$ or $80 \mathrm{ng} / \mathrm{ml})$ for $72 \mathrm{~h}$. Activin-A increased the amount of secreted FSH (Fig. $1 \mathrm{~A})$ as well as the percentage of immunoreactive FSH cells (Fig. 1B) in a dose-dependent manner. Since the maximal effects of activin-A were obtained at $20 \mathrm{ng} / \mathrm{ml}, 25 \mathrm{ng} / \mathrm{ml}(1 \mathrm{nM})$ of activin-A was mainly used in the following experiments.

\section{Effect of activin- $A$ on BrdU incorporation in an- terior pituitary cells}

Cells were cultured with or without activin-A (5, $25 \mathrm{ng} / \mathrm{ml})$ and cytosine arabinoside $(0.4 \mu \mathrm{M})$ in the presence of $\mathrm{BrdU}(10 \mu \mathrm{M})$ for $48 \mathrm{~h}$, and cells were immunostained using BrdU antibody. Activin-A did not cause significant changes in the number of total pituitary cells either in the presence or absence of cytosine arabinoside $(0.4 \mu \mathrm{M})$ (Fig. 2A). Fig. 3 shows BrdU-incorporating cells in representative fields from control (Fig. 3A) and activin-A-treated (Fig. 3B) cultures. No detectable staining was observed when BrdU was omitted from the culture (Fig. 3C), which ascertains the specificity of the BrdUstaining assay. Activin-A caused significant increases in the number of anterior pituitary cells that incorporated BrdU (Fig. 2B, open columns). Activin-A-induced increases in the number of BrdUincorporating cells were abolished when cytosine arabinoside $(0.4 \mu \mathrm{M})$ was also present during the culture period (Fig. 2B, filled columns).

Table 1. Specificity of anti-FSH used for immunocytochemistry

\begin{tabular}{lc}
\hline & $\%$ of stained cells \\
\hline anti-FSH $(1: 1,500)$ & $6.30 \pm 0.45$ \\
anti-FSH $(1: 1,500)+$ FSH $(12.5 \mu \mathrm{g} / \mathrm{ml})$ & 0 \\
anti-FSH $(1: 1,500)+\mathrm{LH}(12.5 \mu \mathrm{g} / \mathrm{ml})$ & $6.22 \pm 0.24$ \\
\hline
\end{tabular}

Anti-rat FSH, anti-rat FSH plus NIDDK-r-FSH-I-8, and anti-rat FSH plus NIDDK-r-LH-I-9 were incubated for $24 \mathrm{~h}$ at $4^{\circ} \mathrm{C}$, and then used for immunocytochemistry. Data are the mean \pm SEM of triplicate samples. 
(A)

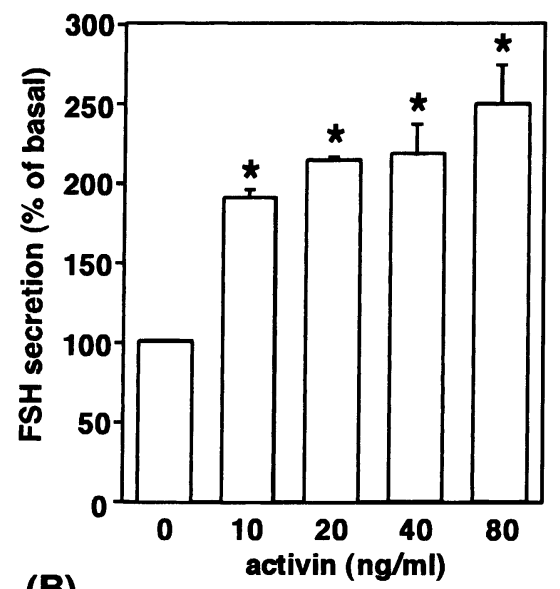

(B)

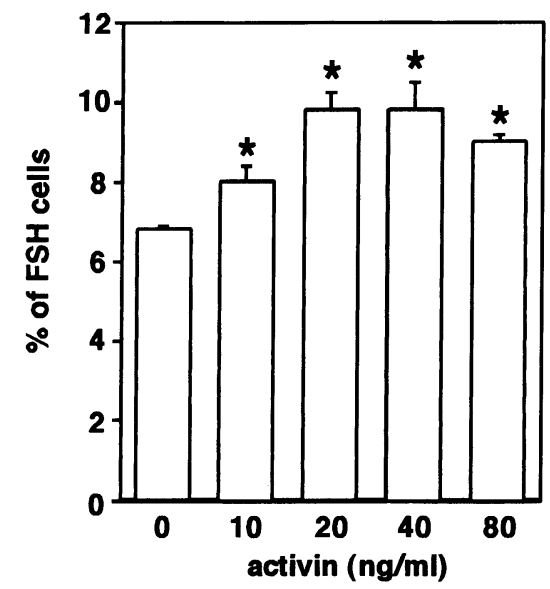

(A)

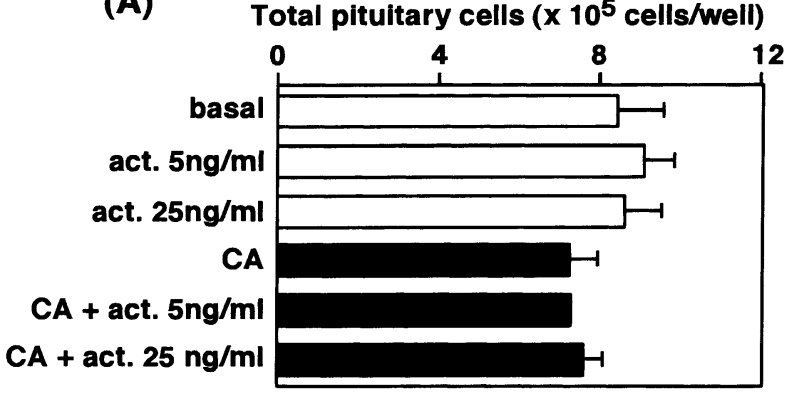

(B)

Numbers of BrdU-incorporating cells (x $10^{5}$ cells/well)

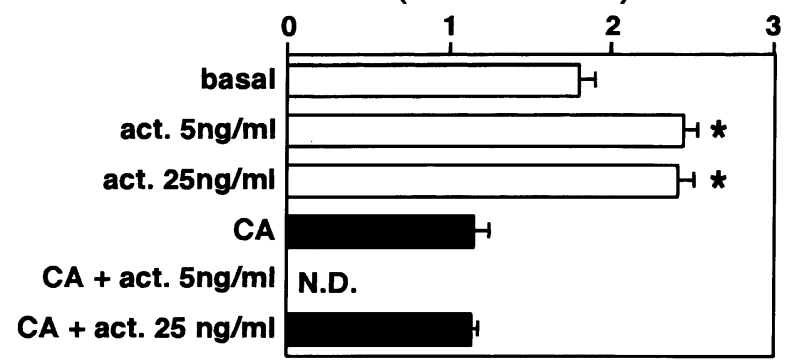

Fig. 2. Effects of activin-A on the number of total pituitary cells and of BrdU-incorporating cells. Anterior pituitary cells were cultured with or without activin-A (act.; $5,25 \mathrm{ng} / \mathrm{ml}$ ) and cytosine arabinoside (CA; $0.4 \mu \mathrm{M})$ in the presence of $\operatorname{BrdU}(10 \mu \mathrm{M})$ for $48 \mathrm{~h}$. The total numbers of cells were counted (A), the percentages of BrdU-incorporating cells were determined, and the number of BrdU-incorporating cells were calculated (B). ${ }^{*}, \mathrm{P}<0.05$ vs. basal values

addition of activin-A significantly induced further increases in the percentage of immunoreactive FSH cells in the presence of cytosine arabinoside (Fig. 4B). Two-way ANOVA indicated that the presence of cytosine arabinoside did not significantly influence the effects of activin-A either on FSH secretion or on the percentage of immunoreactive FSH cells.

\section{Effects of calcium ion-dependent-signaling inhibi- tors on FSH secretion}

Effectiveness of $\mathrm{KN}-62(5 \mu \mathrm{M})$ and nicardipine $(1 \mu \mathrm{M})$ was examined by treatments with these inhibitors for $72 \mathrm{~h}$ and following stimulation with A23187 $(100 \mu \mathrm{M})$ and high potassium buffer, respectively, for $4 \mathrm{~h}$. Pretreatment with KN-62 significantly reduced A23187-stimulated FSH secretion, and that with nicardipine significantly reduced high potassium buffer-induced FSH secretion (Fig. 5A). 
A

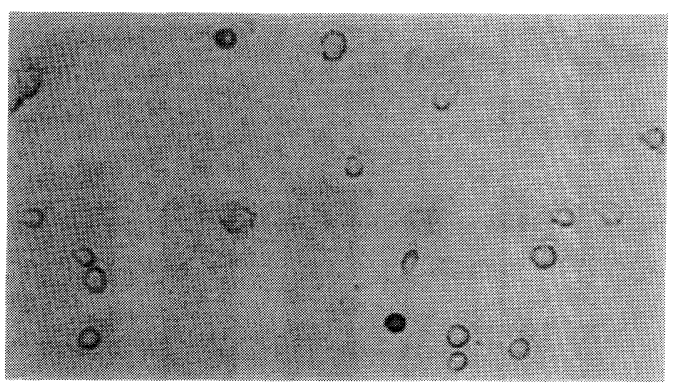

B

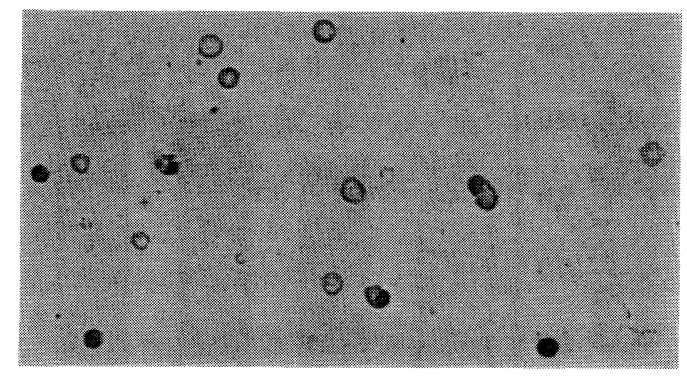

C

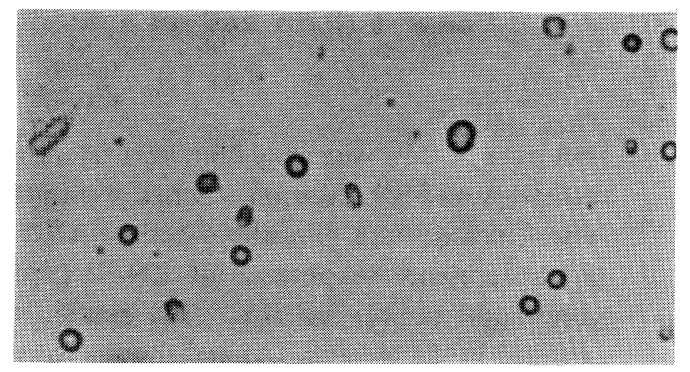

Fig. 3. Photographs of BrdU-incorporating cells. Anterior pituitary cells were cultured with or without activinA $(25 \mathrm{ng} / \mathrm{ml})$ in the presence or absence of BrdU $(10 \mu \mathrm{M})$ for $48 \mathrm{~h}$, and were immunostained with BrdU antibody. (A), cells treated without activin-A (control); (B), cells treated with activin-A; (C), cells treated in the absence of BrdU (negative control).

Meanwhile, total FSH, the sum of secreted and intracellular FSH, was not significantly affected by either of these inhibitors (Fig. 5B), nor was the cell viability significantly affected by these inhibitors (data not shown).

\section{Effects of calcium ion-dependent-signaling inhibi- tors on activin actions}

Cells were cultured with or without activin-A $(25 \mathrm{ng} / \mathrm{ml})$ in the presence or absence of $\mathrm{KN}-62$ $(5 \mu \mathrm{M})$ or nicardipine $(1 \mu \mathrm{M})$ for $72 \mathrm{~h}$. Activin-A significantly increased the secretion of FSH, and
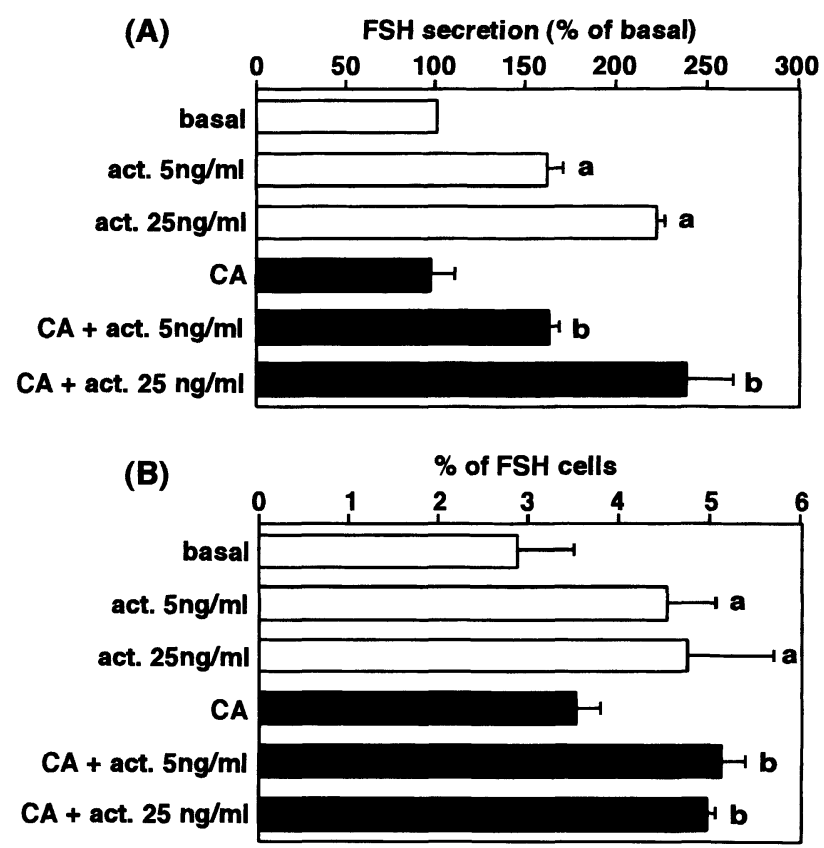

Fig. 4. Influence of cytosine arabinoside on the effects of activin-A. Anterior pituitary cells were cultured with or without activin-A (act.; $5,25 \mathrm{ng} / \mathrm{ml}$ ) in the presence (filled columns) or absence (open columns) of cytosine arabinoside (CA; $0.4 \mu \mathrm{M})$ for $72 \mathrm{~h}$. The amount of FSH secreted in the medium (A) and the percentage of FSH cells among total cells (B) were determined. a, $\mathrm{P}<0.05$ vs. basal values; $\mathrm{b}, \mathrm{P}<0.05$ vs. CA

neither inhibitor significantly affected the effect of activin-A (Fig. 6A). Activin-A also significantly increased total FSH, the sum of secreted and intracellular contents of $\mathrm{FSH}$, in the presence of these inhibitors (Fig. 6B). On the other hand, the stimulatory effect of activin-A on the percentage of immunoreactive FSH cells was abolished by the presence of either of these inhibitors (Fig. 7).

\section{Discussion}

The present study first demonstrated that BrdU incorporation, an index of cellular proliferation, was increased under the stimulation of activin-A in primary cultures of anterior pituitary cells. BrdU incorporation was observed even under the basal condition. Occurrence of proliferation in cultured anterior pituitary cells was formerly demonstrated [11], although the identity of the proliferating cells 

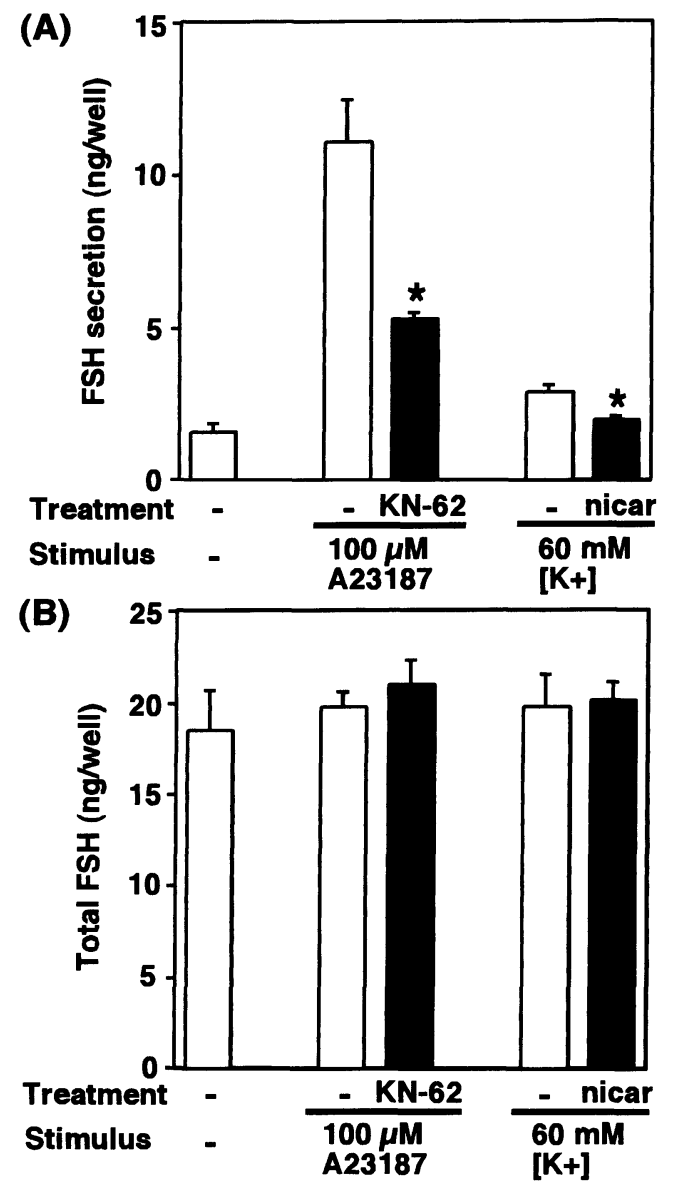

Fig. 5. Effects of $\mathrm{Ca}^{2+}$-signaling inhibitors on FSH secretion. Anterior pituitary cells were cultured in medium only, with $\mathrm{KN}-62(5 \mu \mathrm{M})$, or with nicardipine (nicar.; $1 \mu \mathrm{M}$ ) for $72 \mathrm{~h}$. Then, cells were incubated in medium only, in medium containing A23187 $(100 \mu \mathrm{M})$ or in high potassium buffer for $4 \mathrm{~h}$. The amount of FSH secreted in the medium (A) and the sum of medium and intracellular FSH (total FSH; B) were determined. ${ }^{*}, \mathbf{P}<0.05$ vs. corresponding control values that were cultured without inhibitors

remains unclear. Our results confirm this classic observation and also suggest that activin-A has an ability to enhance proliferation of pituitary cells. Since the total number of pituitary cells was not altered by activin-A treatment, it is possible that activin-A has an ability to induce "death" of pituitary cells, besides increasing their proliferation. As activin-A has been demonstrated to be involved in apoptosis in other tissues such as hepatocytes $[12,13]$ or B lymphocytes [14-16], it remains to be examined whether activin-A is also able to induce apoptosis of

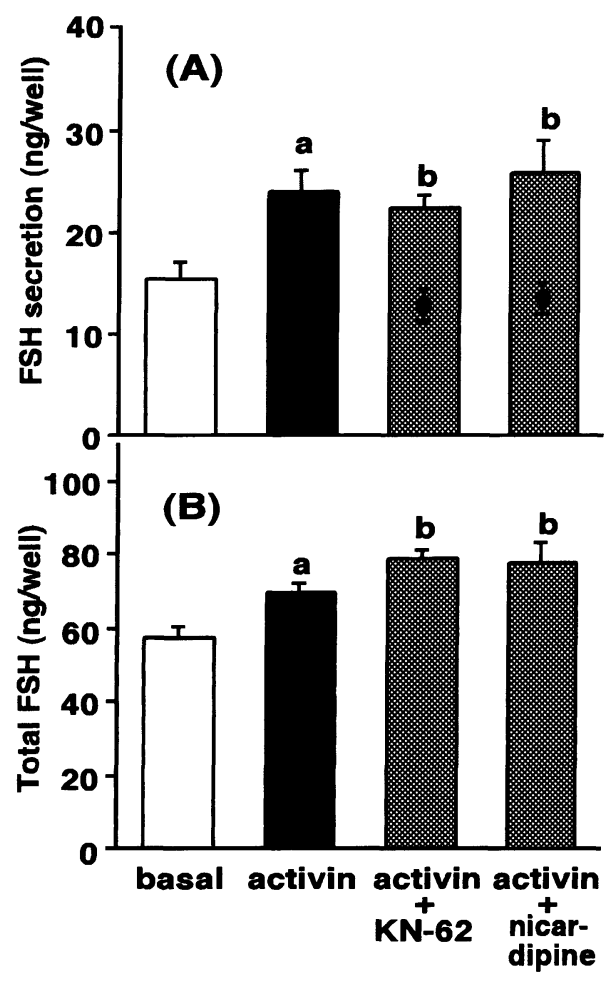

Fig. 6. Influence of $\mathrm{Ca}^{2+}$-signaling inhibitors on the effect of activin-A on FSH secretion. Anterior pituitary cells were cultured with or without activin-A $(25 \mathrm{ng} / \mathrm{ml})$ in the presence or absence of $\mathrm{KN}-62(5 \mu \mathrm{M})$ and nicardipine $(1 \mu \mathrm{M})$ for $72 \mathrm{~h}$. The amount of FSH secreted in the medium (A) and the sum of medium and intracellular FSH (total FSH; B) were determined. Circles and bars in right two columns in (A) indicate the mean \pm SE of basal FSH secretion in the presence of corresponding inhibitors. a, $\mathrm{P}<0.05 \mathrm{vs.}$ basal values; $\mathrm{b}, \mathrm{P}<0.05$ vs. basal values, $\mathrm{P}>0.05$ vs. activin

pituitary cells.

Activin has been shown to stimulate proliferation of several cell types, such as bone marrow erythroid progenitor cells [17-19], vascular smooth muscle cells [20] and fibroblasts [21, 22]. With respect to pituitary cells, activin suppresses, but does not stimulate, proliferation of the $\mathrm{GH}_{4} \mathrm{C}_{1}$ rat pituitary cell line [23] and GRF-stimulated proliferation of purified somatotropes [24]. We were unable to detect an effect of activin-A on proliferation of the pituitary folliculo-stellate-like cell line, TtT/GF [25] (unpublished observation by Tetsuro Katayama). Although the cells whose proliferation activity is stimulated by activin-A do not appear to be involved in the effects 


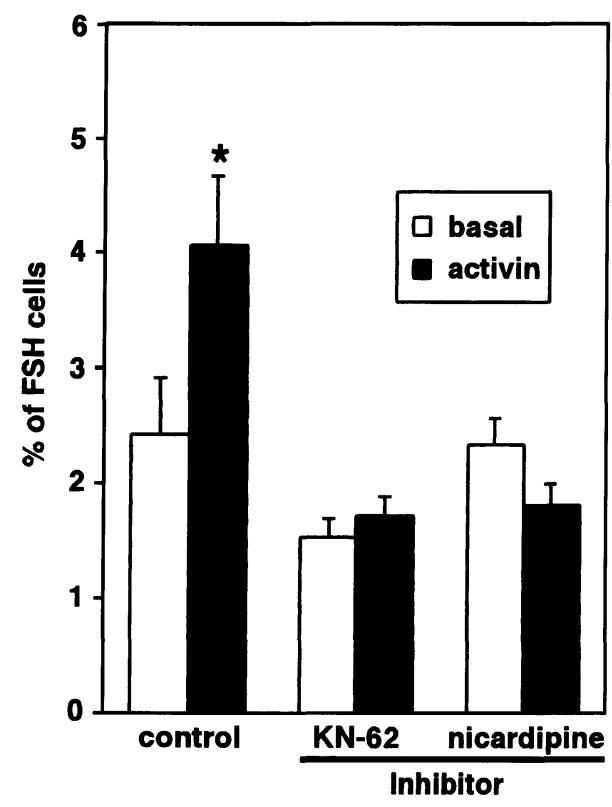

Fig. 7. Influence of $\mathrm{Ca}^{2+}$-signaling inhibitors on the effect of activin-A on the percentage of FSH cells. Anterior pituitary cells were cultured with or without activinA $(25 \mathrm{ng} / \mathrm{ml})$ in the presence or absence of $\mathrm{KN}-62$ $(5 \mu \mathrm{M})$ and nicardipine $(1 \mu \mathrm{M})$ for $72 \mathrm{~h}$. The percentages of immunoreactive FSH cells among total cells were determined. ${ }^{*}, \mathrm{P}<0.05$ vs. corresponding basal values

of activin-A on FSH gonadotropes, these cells may be involved in other effects of activin-A. Further studies are required to identify these cells.

We next examined whether the increase in cellular proliferation is essential for activin-A to exhibit its dual effect on FSH gonadotropes, that is, augmentation of FSH secretion and enlargement of FSH cell population [7]. A mitotic inhibitor, cytosine arabinoside, which abolished activin-A-induced proliferation, did not attenuate the stimulatory effects of activin-A on FSH secretion and on the percentage of immunoreactive FSH cells. These results indicate that activin-A induces increases in FSH secretion and in the number of immunoreactive FSH cells independent of cellular proliferation. The cytosine arabinoside-induced baseline rise in the percentage of immunoreactive FSH cells probably resulted from suppression of mitotic activity of vigorously proliferating cells, which led to decreases in the percentage of such cells and concomitant increases in that of immunoreactive FSH cells.

The present study finally demonstrated that ac-
tivin-A appears to induce increases in FSH secretion and enlargement of FSH cell population through distinct intracellular signaling pathways; the former through $\mathrm{Ca}^{2+}$-independent and the latter through $\mathrm{Ca}^{2+}$-dependent mechanisms. In human FSHsecreting pituitary adenoma cells, activin-A was shown to increase the amplitude of the L-type $\mathrm{Ca}^{2+}$ current [26] and activin-A-induced increases in FSH secretion were blocked in $\mathrm{Ca}^{2+}$-deficient medium or by an L-type $\mathrm{Ca}^{2+}$ channel blocker [27]. On the contrary, Tasaka et al. [28, 29], using normal rat pituitary cells, demonstrated that subsets of somatotropes and lactotropes, but few gonadotropes, showed increases in cytosolic free $\mathrm{Ca}^{2+}$ concentration in response to activin-A. Our results demonstrating ineffectiveness of $\mathrm{Ca}^{2+}$-related signaling inhibitors, $\mathrm{KN}-62$ and nicardipine, on activin-A-induced increases in FSH secretion in primary rat anterior pituitary cultures are in good agreement with their observation.

Mice deficient in activin receptor type II have been shown to lack normal development of pituitary FSH gonadotropes [30], suggesting that activin receptor type II plays a critical role in the development of FSH gonadotropes. On the other hand, a study using prepubertal female rat pituitaries demonstrated that activin receptor type II mRNA was generally not expressed in FSH-immunoreactive cells, while activin receptor type IIB mRNA was expressed in FSHimmunoreactive cells [31]. Taken together, these results are indicative of different types of target cells being responsible for activin-stimulated FSH secretion and activin-induced development of FSH gonadotropes. This view is also consistent with our previous observation that different fractions of pituitary cells responded to activin-A to increase FSH secretion and to enlarge the population of FSH gonadotropes [9]. Results in the present study give additional indication of activin acting through distinct mechanisms on different subsets of pituitary cells in its dual effect on FSH gonadotropes. Further studies are needed to clarify the type(s) of activin receptor-expressing pituitary cells that are involved in the development of FSH gonadotropes.

\section{Acknowledgments}

We are grateful to Dr. Y. Eto, Central Research 
Laboratory of Ajinomoto Co., Kawasaki, Japan, for the gift of human recombinant activin $\mathrm{A}$. The authors also thank NIDDK's National Hormone \&
Pituitary Program and Dr. A. F. Parlow for kindly providing us with the RIA reagents.

\section{References}

1. Massague J (1990) The transforming growth factor- $\beta$ family. Annu Rev Cell Biol 6: 597-641.

2. Vale W, Rivier J, Vaughan J, McClintock R, Corrigan A, Woo W, Karr D, Spiess J (1986) Purification and characterization of an FSH releasing protein from ovarian follicular fluid. Nature 321: 776-779.

3. Ling N, Ying S-Y, Ueno N, Shimasaki S, Esch F, Hotta M, Guillemin R (1986) Pituitary FSH is released by a heterodimer of the $\beta$-subunits from the two forms of inhibin. Nature 321: 779-782.

4. Eto Y, Tsuji T, Takezawa M, Takano S, Yokogawa Y, Shibai H (1987) Purification and characterization of erythroid differentiation factor (EDF) isolated from human leukemia cell line THP-1. Biochem Biophys Res Commun 142: 1095-1103.

5. Murata M, Eto Y, Shibai H, Sakai M, Muramatsu M (1988) Erythroid differentiation factor is encoded by the same mRNA as that of the inhibin $\beta A$ chain. Proc Natl Acad Sci USA 85: 2434-2438.

6. Meunier H, Rivier C, Evans RM, Vale W (1988) Gonadal and extragonadal expression of inhibin $\alpha$, $\beta A$, and $\beta B$ subunits in various tissues predicts diverse functions. Proc Natl Acad Sci USA 85: 247-251.

7. Katayama T, Shiota K, Takahashi M (1990) Activin A increases the number of follicle-stimulating hormone cells in anterior pituitary cultures. Mol Cell Endocrinol 69: 179-185.

8. Katayama T, Shiota K, Sugino H, Takahashi M (1992) Paracrine effect of folliculo-stellate cells on the growth factor-like action of activin $\mathrm{A}$ in anterior pituitary cultures. Endocrinol Japon 39: 289-297.

9. Katayama T, Shiota K, Takahashi M (1991) Effects of activin $\mathrm{A}$ on anterior pituitary cells fractionated by centrifugal elutriation. Mol Cell Endocrinol 77: 167173.

10. Hunter WM, Greenwood FS (1962) Preparation of iodine-131 labeled growth hormone of high specific activity. Nature 194: 495-496.

11. Khar A, Debeljuk L, Jutisz M (1978) Effect of hypothalamic extracts on the incorporation of $\left[{ }^{3} \mathrm{H}\right]-$ thymidine by pituitary cells in culture. Proc Soc Exp Biol Med 158: 471-474.

12. Hully JR, Chang L, Schwall RH, Widmer HR, Terrell TG, Gillett NA (1994) Induction of apoptosis in the murine liver with recombinant human activin A. Hepatology 20: 854-862.

13. Zhang YQ, Kanzaki M, Mashima H, Mine T, Kojima
I (1996) Norepinephrine reverses the effects of activin A on DNA synthesis and apoptosis in cultured rat hepatocytes. Hepatology 23: 288-293.

14. Nishihara $T$, Ohsaki $Y$, Ueda N, Koseki T, Eto $Y$ (1995) Induction of apoptosis in B lineage cells by activin A derived from macrophages. J Interferon Cytokine Res 15: 509-516.

15. Hashimoto $\mathrm{O}$, Yamato $\mathrm{K}$, Koseki $\mathrm{T}$, Ohguchi $\mathrm{M}$, Ishisaki A, Shoji H, Nakamura T, Hayashi Y, Sugino $H$, Nishihara T (1998) The role of activin type I receptors in activin A-induced growth arrest and apoptosis in mouse B-cell hybridoma cells. Cell Signal 10: 743-749.

16. Ishisaki A, Yamato K, Nakao A, Nonaka K, Ohguchi $M$, ten Dijke P, Nishihara T (1998) Smad7 is an activin-inducible inhibitor of activin-induced growth arrest and apoptosis in mouse B cells. $J$ Biol Chem 273: 24293-24296.

17. Yu J, Shao L, Lemas V, Yu AL, Vaughan J, Rivier J, Vale W (1987) Importance of FSH-releasing protein and inhibin in erythrodifferentiation. Nature 330: 765-767.

18. Broxmeyer HE, Lu L, Cooper S, Schwall RH, Mason AJ, Nikolics K (1988) Selective and indirect modulation of human multipotential and erythroid hematopoietic progenitor cell proliferation by recombinant human activin and inhibin. Proc Natl Acad Sci USA 85: 9052-9056.

19. Shiozaki M, Sakai R, Tabuchi M, Nakamura T, Sugino K, Sugino H, Eto Y (1992) Evidence for the participation of endogenous activin A/erythroid differentiation factor in the regulation of erythropoiesis. Proc Natl Acad Sci USA 89: 1553-1556.

20. Kojima I, Mogami H, Kawamura N, Yasuda H, Shibata H (1993) Modulation of growth of vascular smooth muscle cells by activin A. Exp Cell Res 206: 152-156.

21. Kojima I, Ogata E (1989) Dual effect of activin A on cell growth in BALB/C 3T3 cells. Biochem Biophys Res Commun 159: 1107-1113.

22. Hedger MP, Drummond AE, Robertson DM, Risbridger GP, de Kretser DM (1989) Inhibin and activin regulate $\left[{ }^{3} \mathrm{H}\right]$ thymidine uptake by rat thymocytes and 3T3 cells in vitro. Mol Cell Endocrinol 61: 133-138.

23. Ramsdell JS (1991) Transforming growth factor- $\alpha$ and $-\beta$ are potent and effective inhibitors of $\mathrm{GH}_{4}$ pituitary tumor cell proliferation. Endocrinology 128: 
1981-1990.

24. Billestrup N, González-Manchón C, Potter E, Vale W (1990) Inhibition of somatotroph growth and growth hormone biosynthesis by activin in vitro. Mol Endocrinol 4: 356-362.

25. Inoue $\mathrm{K}$, Matsumoto $\mathrm{H}$, Koyama $\mathrm{C}$, Shibata $\mathrm{K}$, Nakazato Y, Ito A (1992) Establishment of a folliculo-stellate-like cell line from a murine thyrotropic pituitary tumor. Endocrinology 131: 3110-3116.

26. Takano K, Ogata E, Yamashita N (1994) Effects of activin A on ionic channels in human FSH-secreting tumour cells. J Physiol Lond 474: 65-73.

27. Takano K, Yamashita N, Kojima I, Kitaoka M, Teramoto A, Ogata E (1992) Effects of activin A and somatostatin on intact FSH secretion and intracellular $\mathrm{Ca}^{2+}$ concentration in human FSH-secreting pituitary adenoma cells. Biochem Biophys Res Commun 182: 1408-1415.
28. Tasaka K, Kasahara K, Masumoto N, Mizuki J, Kurachi H, Miyake A, Tanizawa O (1992) Activin A increases cytosolic free calcium concentration in rat pituitary somatotropes. Biochem Biophys Res Commun 185: 974-980.

29. Tasaka K, Kasahara K, Masumoto N, Mizuki J, Fukami K, Miyake A, Nakamura T, Sugino H (1994) Characterization of activin A-, activin AB- and activin B-responding cells by their responses to hypothalamic releasing hormones. Biochem Biophys Res Commun 203: 1739-1744.

30. Matzuk MM, Kumar TR, Bradley A (1995) Different phenotypes for mice deficient in either activins or activin receptor type II. Nature 374: 356-360.

31. Wilson ME, Handa RJ (1998) Activin subunit, follistatin, and activin receptor gene expression in the prepubertal female rat pituitary. Biol Reprod 59: 278-283. 